\title{
Implementasi Peraturan Bupati Nomor 43 Tahun 2014 Tentang SOP Pelayanan PBB-P2 Di Badan Pendapatan Daerah Kabupaten Bengkalis
}

\author{
Riza Zuhelmy ${ }^{1}$, Adinto ${ }^{2}$ \\ ${ }^{12}$ Program Studi Pascasarjana Ilmu Administrasi Publik Universitas Riau \\ Korespondensi : adinto@lecturer.unri.ac.id
}

\begin{abstract}
Abstrak
Pajak Bumi Bangunan Perdesaan dan Perkotaan (PBB-P2) merupakan bentuk kontribusi wajib yang harus dibayarkan kepada pemerintah Kabupaten/Kota dan bersifat memaksa serta tidak mendapatkan imbalan secara langsung. Dasar pengenaan PBB P2 adalah Nilai Jual Objek Pajak (NJOP). Dengan adanya peralihan ini diharapkan pemerintah daerah Kabupaten Bengkalis dapat meningkatkan PAD dari sektor pungutan PBB-P2. Karena jika pungutan PBB P2 lebih dioptimalkan, hasilnya dapat dimanfaatkan untuk pembangunan daerah.

Tujuan penelitian ini adalah untuk mengetahui bagaimana Implementasi Peraturan Bupati Nomor 43 Tahun 2014 tentang SOP Pelayanan PBB-P2 di Badan Pendapatan Daerah Kabupaten Bengkalis, apa saja faktor yang menjadi penghambat mempengaruhi Implementasi SOP Pelayanan PBB-P2 di Badan Pendapatan Daerah Kabupaten Bengkalis dan bagaimana Upaya Badan Pendapatan Daerah Bengkalis dalam Implementasi Peraturan Bupati Nomor 43 Tahun 2014 Tentang Sop Pelayanan PBB-P2, Penelitian ini menggunakan pendekatan metode penelitian deskriptif kualitatif. Data primer diperoleh langsung melalui wawancara dari informan, yaitu Kepala Badan Pendapatan Daerah Kabupaten Bengkalis. Data Sekunder diperoleh melalui media online, jurnal dan tesis yang berkaitan dengan SOP Pelayanan PBB-P2.

Hasil penelitian ini menunjukkan bahwa tidak terealisasinya target penerimaan PBB P2 yaitu karena kurangnya kesadaran yang dimiliki oleh wajib pajak (WP) dalam melunasi kewajibannya membayar pajak berdasarkan ketetapan pokok Surat Pemberitahuan Pajak Terutang (SPPT) dan seolah didukung dengan tidak adanya penegakan hukum berupa sanksi yang tegas kepada wajib pajak yang menunggak pembayaran PBB P2 baik berupa surat paksa maupun penyitaan.
\end{abstract}

Kata kunci: Implementasi, Pelayanan, PBB-P2

\section{Abstract}

Rural and Urban Land and Building Tax (PBB-P2) is a form of compulsory contribution that must be paid to district / city governments and is compelling and does not receive direct compensation. The basis for imposition of PBB-P2 is the Sales Value of Tax Objects (NJOP). With this transition, it is hoped that the local government of Bengkalis Regency can increase PAD from the PBB-P2 levy sector. Because if the PBB-P2 levy is more optimized, the results can be used for regional development.

The purpose of this study was to find out how the implementation of the Regent's Regulation Number 43 of 2014 concerning the SOP for PBB-P2 Service in the Bengkalis Regency Regional Revenue Agency, what are the factors that become obstacles affecting the implementation of PBB-P2 Service SOP in the Bengkalis Regency Regional Revenue Agency and how the Agency's Efforts Bengkalis Regional Revenue in the Implementation of Regent Regulation Number 43 of 2014 concerning Sop PBB-P2 Services, This research uses a qualitative descriptive research method approach. Primary data were obtained directly through interviews from informants, namely the Head of the Bengkalis Regency Regional Revenue Agency. Secondary data were obtained through online media, journals and theses related to the PBB-P2 Service SOP.

The results of this study indicate that the realization of the PBB-P2 revenue target is due to the lack of awareness of taxpayers (WP) in paying off their tax obligations based on the principal provisions of Tax Returns Payable (SPPT) and as if it is supported by the absence of law enforcement in the form of strict sanctions. to taxpayers who are in arrears for PBB-P2 payments, either in the form of forced letters or confiscation.

Keywords: Implementation, Services, $P B B-P 2$ 


\section{PENDAHULUAN}

Implementasi kebijakan otonomi secara efektif pada realitasnya memberikan proses pembelajaran berharga terutama esensinya dalam kehidupan membangun demokrasi, kebersamaan, keadilan, pemerataan dan keanekaragaman daerah dalam kesatuan melalui dorongan pemerintah untuk tumbuh dan berkembangnya prakarsa awal (daerah dan masyarakatnya) menuju kesejahteraan masyarakat. Prinsip dasar otonomi daerah dalam rangka penyelenggaraan pemerintahan daerah secara konsepsional adalah: pendelegasian kewenangan (delegation of autority), pembagian pendapatan (income sharing), kekuasaan (dicreation), keanekaragaman dalam kesatuan (uniformity in unitry), kemandirian lokal dan pengembangan kapasitas daerah (capacity building). Implementasi otonomi daerah memberi dampak positif dan negatif dalam penyelenggaraan pemerintahan dan pembangunan di daerah. Dampak positif yang menonjol adalah tumbuh dan berkembangnya prakarsa daerah menuju kemandirian daerah dalam membangun. Dampak negatifnya yang paling mengemuka timbulnya friksi pusat-daerah dan antar daerah, terutama dalam pengelolaan sumber daya alam, kewenangan dan kelembagaan daerah. (Bewa Ragawino, 2003)

Realitas efek implementasi otonomi daerah yang dirasakan oleh berbagai daerah, pada dasarnya tetap membuka kesempatan dan peluang bagi daerah untuk terus berkembang. Karena implementasi kebijakan otonomi daerah berimplikasi pada pembangunan daerah. Dimana pembangunan daerah yang diharapkan adalah terwujudnya kemandirian daerah dalam pengelolaan pembangunan secara serasi, profesional, dan berkelanjutan. Dalam konteks tersebut, pembangunan daerah yang dilakukan pemerintah pada daerah dalam rangka reposisi paradigma baru pembangunan daerah yang berbasis kewilayahan, kemitraan pembangunan, lingkungan hidup, serta penerapan good governance.

Pelaksanaan Otonomi Daerah yang dilakukan oleh setiap Pemerintah Daerah diarahkan untuk mempercepat terwujudnya kesejahteraan masyarakat melalui peningkatan pelayanan, pembangunan infrastruktur, pemberdayaan dan peran serta masyarakat. Hal ini tentunya membutuhkan kekuatan keuangan daerah yang baik dalam upaya mendukung proses pembangunan daerah dan perwujudan kesejahteraan masyarakat. Oleh karena itu, sumber keuangan daerah yang dimiliki harus dikelola dengan efektif dan efisien supaya bisa memberikan kontribusi yang positif dalam implementasi otonomi daerah. Salah satu sumber keuangan daerah berasal dari Pendapatan Asli Daerah (PAD) yang merupakan pendapatan diperoleh Daerah yang dipungut berdasarkan Peraturan Daerah sesuai dengan peraturan perundang-undangan.

Pendapatan Asli Daerah (PAD) merupakan tingkat kemandirian suatu daerah, dimanasemakin tinggi pemasukan yang diperoleh maka semakin tinggi pula tingkat kemandirian daerah tersebut. Oleh karenanya, Pemerintah Daerah harus mengoptimalkan pengelolaan sumber pendapatan daerah yang berasal dari Pendapatan Asli Daerah (PAD). Sumber Pendapatan Asli Daerah (PAD) berasal dari pajak daerah, retribusi daerah, hasil pengelolaan kekayaan daerah yang dipisahkan dan lain-lain pendapatan asli daerah yang sah. Keseluruhan sumber Pendapatan Asli Daerah (PAD) tersebut harus dimaksimalkan perolehannya, agar memberikan support dalam pelaksanaan pembangunan daerah dan kesejahteraan masyarakat dalam konteks kemandirian daerah.

Salah satu sumber Pendapatan Asli Daerah (PAD) berasal dari pajak daerah. Pajak daerah menurut Undang-undang No. 28 Tahun 2009 tentang pajak daerah dan retribusi daerah, menjelaskan bahwa pajak daerah adalah kontribusi wajib kepada daerah yang terutang oleh orang pribadi atau badan yang bersifat memaksa berdasarkan Undang-undang, dengan tidak mendapatkan imbalan secara langsung dan digunakan untuk keperluan daerah bagi sebesar-besarnya kemakmuran rakyat. Berdasarkan konsep tersebut, maka pajak daerah adalah kontribusi wajib kepada daerah yang memiliki esensi seperti: 1). bersifat memaksa, 2). berdasarkan undang-undang, 3). tidak mendapatkan imbalan secara langsung, 4). digunakan untuk keperluan daerah bagi sebesar-besarnya kemakmuran rakyat. 
Pajak daerah mempunyai peran penting dalam pelaksanaan fungsi, yaitu: Pertama, fungsi penerimaan (Budgetair), dimana fungsi yang paling utama dari pajak daerah adalah untuk mengisi kas daerah. Fungsi ini disebut fungsi budgetair yang secara sederhana dapat diartikan sebagai alat pemerintah daerah untuk menghimpun dana dari masyarakat untuk berbagai kepentingan pembiayaan pembangunan daerah. Fungsi ini juga tercermin dalam prinsip efisiensi yang menghendaki pemasukan yang sebesarbesarnya dengan pengeluaran yang sekecil-kecilnya dari suatu penyelenggaraan pemungutan pajak daerah. Kedua, fungsi pengaturan (Regulerend), dimana fungsi lain dari pajak daerah adalah untuk mengatur atau regulerend. Dalam hal ini pajak daerah dapat digunakan oleh pemerintah daerah sebagai instrumen untuk mencapai tujuan-tujuan tertentu. Dalam hal ini, pengenaan pajak daerah dapat dilakukan untuk mempengaruhi tingkat konsumsi dari barang dan jasa tertentu.

Kabupaten Bengkalis merupakan salah satu Kabupaten di Provinsi Riau yang memiliki potensi SDA yang baik dan letak yang strategis karena berdampingan langsung dengan negara tetangga. Posisi wilayah yang strategis membuat Kabupaten Bengkalis masuk ke dalam program Indonesia Malaysia Thailand Growth Triangle (IMT-GT). Program ini merupakan kelompok sub regional ASEAN yang bertujuan untuk meningkatkan perkembangan ekonomi di 32 wilayah di 3 negara, yakni 10 provinsi di Indonesia, 8 negara bagian di wilayah utara Malaysia, dan 14 provinsi di wilayah selatan Thailand. Secara umum tujuan dari Program IMT-GT adalah untuk mempercepat pertumbuhan ekonomi yang dipimpin oleh sektor swasta di wilayah IMT-GT melalui: a). Meningkatkan perdagangan dan investasi dengan memanfaatkan dasar ekonomi yang saling melengkapi serta keunggulan komparatif. b). Meningkatkan ekspor ke seluruh dunia dengan meningkatkan daya saing ekspor dan investasi. c). Meningkatkan kesejahteraan masyarakat melalui pengembangan kesempatan kerja, pendidikan, sosial dan budaya di kawasan IMT-GT. d). Mendorong sektor swasta untuk memainkan peran utama, sementara sektor publik memfasilitasi dan mendukung sebanyak mungkin.

Perkembangan Kabupaten Bengkalis yang tumbuh dari berbagai sektor tersebut, menginspirasi Pemerintah Daerah untuk memiliki visi dan misi pembangunan yang sesuai dengan kebutuhan daerah dan masyarakatnya yaitu: "Mewujudkan Kabupaten Bengkalis Sebagai Model Negeri Maju dan Makmur di Indonesia". Dimana implementasi dari visi ini diterjemahkan dalam beberapa misi, yaitu: Pertama, Terwujudnya pemerintahan yang berwibawa, transparan dan bertanggungjawab serta dapat melaksanakan kepimpinan dengan bijak, berani dan ikhlas. Kedua, Terwujudnya pengelolaan seluruh potensi daerah dan sumber daya manusia untuk kemakmuran rakyat. Ketiga, Terwujudnya penyediaan infrastruktur yang berkualitas untuk kesejahteraan rakyat.

Salah satu misi Pemerintah Kabupaten Bengkalis yang perlu fokus dalam mengimplementasikannya adalah mewujudkan pengelolaan seluruh potensi daerah untuk kemakmuran rakyat. Dimana pengelolaan seluruh potensi daerah berkaitan dengan upaya penerimaan sumber-sumber pendapatan daerah secara maksimal. Sumber pendapatan daerah salah satunya berasal dari pendapatan asli daerah (PAD) sektor pajak daerah. Berdasarkan Peraturan Daerah Kabupaten Bengkalis Nomor 11 Tahun 2011 tentang Pajak Daerah dan Peraturan Daerah Nomor 01 Tahun 2018 tentang Perubahan Atas Peraturan Daerah Kabupaten Bengkalis Nomor 11 Tahun 2011 tentang Pajak Daerah bahwa jenis pajak daerah yang dikelola Pemerintah Kabupaten Bengkalis terdiri dari:

1. Pajak Hotel

2. Pajak Restoran

3. Pajak Hiburan

4. Pajak Reklame

5. Pajak Penerangan Jalan

6. Pajak Mineral Bukan Logam dan Bantuan

7. Pajak Parkir

8. Pajak Saran Burung Walet 
9. Pajak Air Tanah

10. Pajak PBB Perdesaan dan Perkotaan

11. Pajak Bea Perolehan Hak Atas Tanah (BPHTB)

Pelimpahan kewenangan pengelolaan sumber pendapatan daerah yang dilakukan oleh Pemerintah Pusat kepada Pemerintah Daerah Kabupaten yang tertuang dalam Undang-undang Nomor 28 Tahun 2009 tentang Pajak Daerah dan Retribusi Daerah menjelaskan bahwa setiap daerah Kabupaten diberikan kesempatan secara mandiri mengelola sumber pendapatan daerahnya dari sektor pajak untuk membiayai penyelenggaraan pemerintahan dan mewujudkan kesejahteraan masyarakat di daerah. Oleh karenanya, Pemerintah Kabupaten Bengkalis harus mampu mempunyai strategi yang tepat untuk bisa melakukan penerimaan pajak daerah yang maksimal dengan segela potensi yang dimilikinya.

Untuk mendukung keberlanjutan pelaksanaan kewenangan yang dilimpahkan oleh pemerintah pusat kepada daerah, maka pemerintah Kabupaten/ kota setiap tahunnya mempunyai target dan realisasi dalam melaksanakan pemungutan PBB diwilayahnya masing-masing sebagai sumber pendapatan daerah, tetapi dalam pelaksanaannya tidak selalu target tersebut terealisasi dengan sempurna. Terkadang realisasi penerimaan PBB jauh dibawah target yang telah ditetapkan oleh pemerintah Kabupaten /kota terutama yang dipungut di kecamatan dan kelurahan.

Salah satu sumber PAD yang memiliki kontribusi besar dalam penerimaan pendapatan daerah adalah pajak daerah. Pajak daerah merupakan salah satu sumber pendapatan daerah yang penting guna membiayai pelaksanaan pemerintahan daerah dalam melaksanakan pelayanan kepada masyarakat serta mewujudkan kemandirian daerah. Pajak Bumi Bangunan Perdesaan dan Perkotaan (PBB P2) merupakan salah satu jenis pajak daerah yang penerimaannya dapat di optimalkan dan cukup potensial untuk ditingkatkan

Pajak Bumi Bangunan Perdesaan dan Perkotaan (PBB P2) merupakan bentuk kontribusi wajib yang harus dibayarkan kepada pemerintah Kabupaten/Kota dan bersifat memaksa serta tidak mendapatkan imbalan secara langsung. Bentuk kontribusi ini wajib dilunasi oleh wajib pajak di bank atau tempat lain yang telah ditunjuk oleh Bupati. Wajib pajak membayar pajak terhutang berdasarkan Surat Pemberitahuan Pajak Terhutang (SPPT) paling lama enam (6) bulan sejak tanggal diterimanya SPPT, dan apabila tidak dilunasi sampai waktu yang telah ditentukan maka akan dikeluarkan Surat Tagihan Pajak Daerah (STPD) dan dikenakan sanksi administratif bunga sebesar 2\% (dua persen) setiap bulan.

Dasar pengenaan PBB P2 adalah Nilai Jual Objek Pajak (NJOP). Dengan adanya peralihan ini diharapkan pemerintah daerah Kabupaten Bengkalis dapat meningkatkan PAD dari sector pungutan PBB P2. Karena jika pungutan PBB P2 lebih dioptimalkan, hasilnya dapat dimanfaatkan untuk pembangunan daerah. Namun berdasarkan data yang diperoleh, realisasi penerimaan PBB P2 masih jauh dari target yang ditetapkan. Salah satu penyebab tidak terealisasinya target penerimaan PBB P2 yaitu karena kurangnya kesadaran yang dimiliki oleh wajib pajak (WP) dalam melunasi kewajibannya membayar pajak berdasarkan ketetapan pokok Surat Pemberitahuan Pajak Terutang (SPPT) dan seolah didukung dengan tidak adanya penegakan hukum berupa sanksi yang tegas kepada wajib pajak yang menunggak pembayaran PBB P2 baik berupa surat paksa maupun penyitaan. Tentu saja realita ini menjadi salah satu penghambat terlaksananya pembangunan yang telah ditargetkan oleh pemerintah.

Kondisi ini menuntut Badan Pendapatan Daerah (Bapeda) Kabupaten Bengkalis untuk memperhatikan permasalahan yang menyebabkan terhambatnya realisasi penerimaan PBB P2 berdasarkan target yang telah ditetapkan. Selain realisasi penerimaan PBB P2 yang masih jauh dari target pencapaian, kurangnya kemampuan sumber daya manusia yang dimiliki oleh kolektor pemungut pajak di Kecamatan/ Kelurahan yang belum mampu menyelesaikan tugas secara optimal menyebabkan data wajib pajak tidak terakomodir secara update dan hal ini menyebabkan banyaknya masyarakat wajib pajak maupun objek pajak yang lolos dari pungutan Pajak Bumi Bangunan Perdesaan dan Perkotaan (PBB P2). 


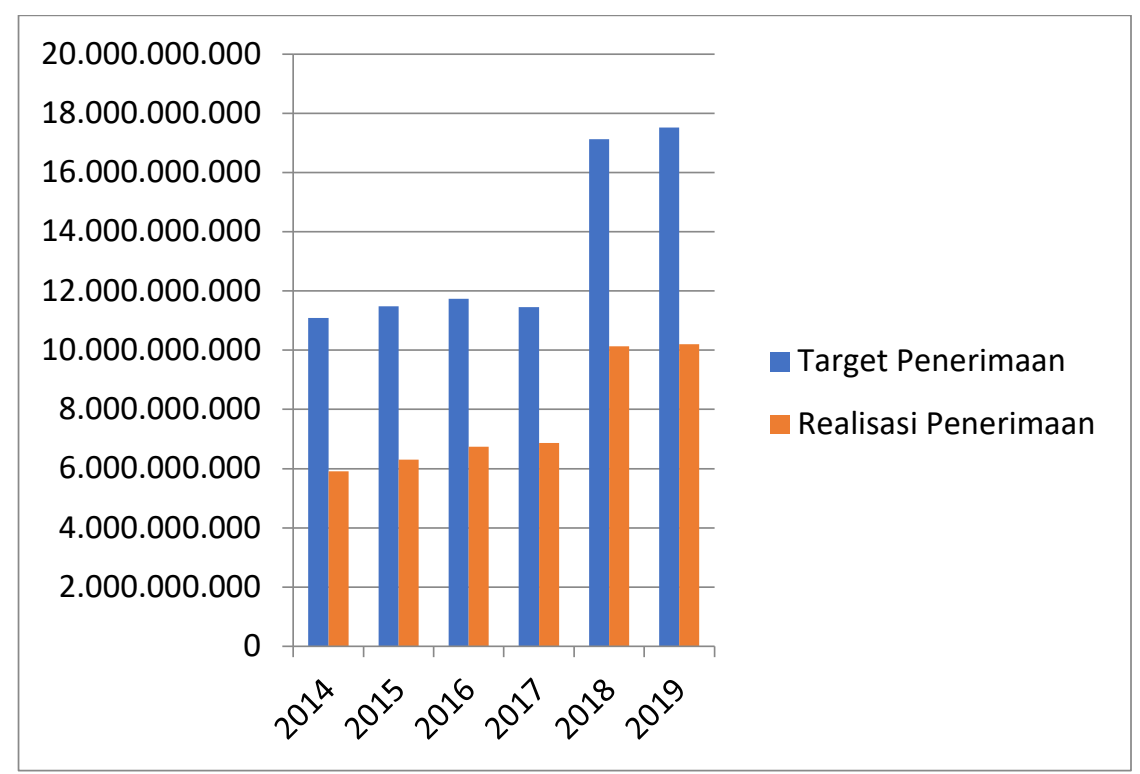

Gambar 1.1 Perbandingan Antara Target Dan Realisasi Penerimaan PBB P2

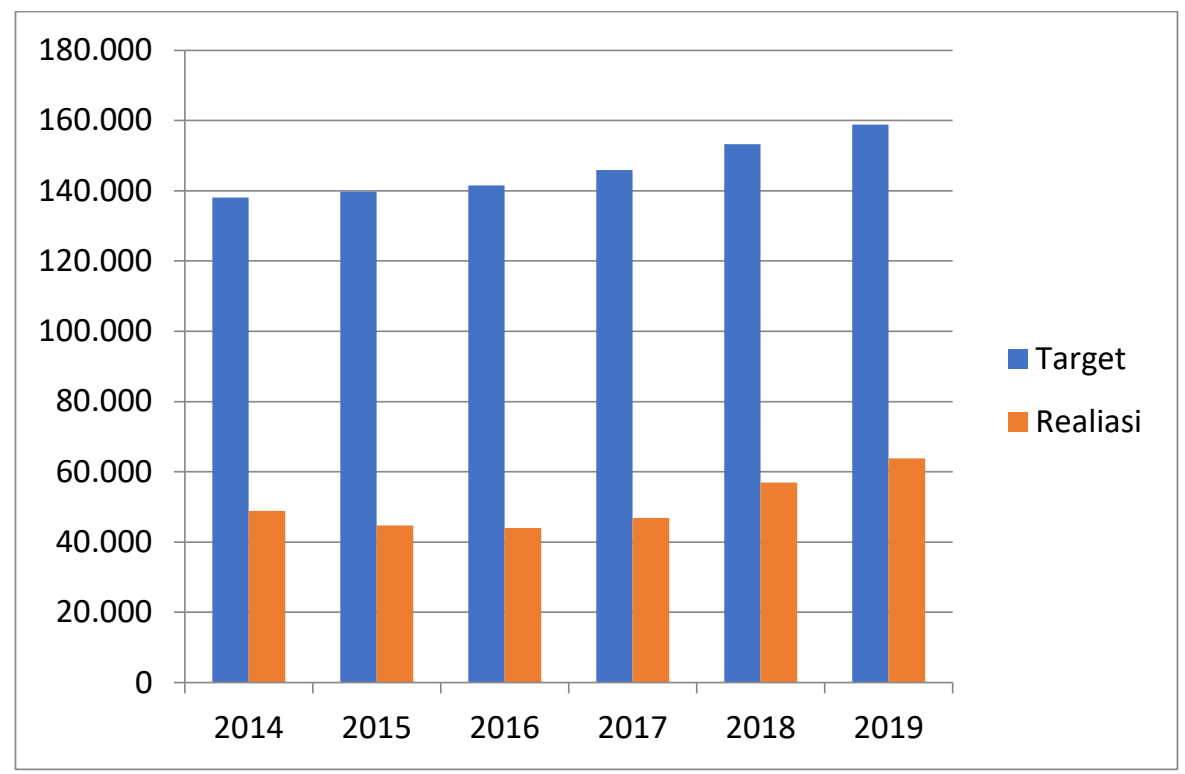

Gambar 1.2 Perbandingan Antara Target SPPT PBB P2 dan Realisasi

Dari gambar tabel data dari Badan Pendapatan Daerah Kabupaten Bengkalis jelas diperlihatkan bahwa, tidak pernah antara target dan penerimaan pajak PBB P2 terjadi penunjukan yang mencapai hasil maksimal. Hal ini terlihat jauhnya rentang antara target dan capaian yang pajak. Baik itu dilihat dari jumlah objek pajak yang ditagih maupun besaran pajak yang diperoleh.

Sepanjang ini hingga tahun 2019 Pemerintah bengkalis telah mengeluarkan beberapa kebijakan dalam meningkatkan PAD dari PBB- P2 yang seharusnya itu sudah berjalan efektik. Salah satunya adalah dengan adanya SOP ( Standar Operasional) dari pungutan tersebut. Serta telah ada beberapa MOU dengan pihak ketiga dalam menjalankan kebijakan pungutan tersebut. Beberapa pihak BANK sudah melakukan MOU misalnya dengan Bank BNI, Bank Riau-KEPRI, Bank BRI jadi masyarakat 
dapat membayar PBB P2 nya langsung kepada Bank Tersebut. Namun dari data yang di dapat masih banyak masyarakat yang membayar langsung ke kantor Dispenda dan itupun pembarannya karena adanya mengurus izin dan lainnya. Kebijakan penagihan berada ditangan petugas yang dibentuk oleh Dispenda, pihak ketiga seperti Bank hanya sebatas tempat pembayaran saja. System penagihan belum pernah berjalan dengan maksimal karena personil dispenda untuk diturunkan kepada masyarakat sedikit.

\section{METODE}

Penelitian ini menggunakan metode kualitatif dengan pendekatan studi kasus agar peneliti dapat lebih mendalam melihat proses Implementasi Peraturan Bupati nomor 43 Tahun 2014 tentang SOP Pelayanan PBB-P2 di Badan Pendapatan Daerah Kabupaten Bengkalis melalui pengumpulan data metode penelitian kualitatif. Dilihat dari wilayahnya, maka penelitian studi kasus hanya meliputi daerah atau subyek yang sangat sempit tetapi ditinjau dari objek atau sifat penelitian maka penelitian studi kasus lebih mendalam. Adapun tujuan dari penelitian ini menggunakan analisis deskriptif adalah untuk mengungkapkan dan menggambarkan kejadian atau fakta, keadaan, fenomena, variabel dan keadaan yang terjadi saat penelitian berlangsung dengan menyuguhkan apa yang sebenarnya terjadi tanpa menambah dan mengurangi.Penelitian ini dilakukan di Badan Pendapatan Daerah Kabupaten Bengkalis Provinsi Riau. Alasan peneliti memilih lokasi penelitian ini dikarenakan untuk mengetahui bagaimana Implementasi Kebijakan Pajak Bumi dan Bangunan Perdesaan dan Perkotaan (PBB-P2) di Badan Pendapatan Daerah Kabupaten Bengkalis. Dalam penelitian ini, dipilih informan-informan yang mengetahui tentang Implementasi Kebijakan Pajak Bumi dan Bangunan Perdesaan dan Perkotaan. Maka untuk memperoleh informan peneliti menggunakan metode purposive sampling yaitu pengambilan informan yang dipilih berdasarkan kriteria-kriteria atau ciri-ciri khusus yang sesuai dan memiliki kompetensi, artinya subjek tersebut memahami dan menguasai permasalahan, dan bersedia memberikan informasi yang lengkap dan akurat terkait dengan data-data yang dibutuhkan dalam penelitian ini :

1. Implementor Kebijakan

a. Kepala Badan Pendapatan Daerah Kabupaten Bengkalis Bapak Supardi, S.Sos, MH. Berperan sebagai perancang sekaligus pelaksana pelayanan pengurusan Pajak Bumi dan Bangunan Perdesaan dan Perkotaan dengan tujuan melihat bagaimana proses pelayanan dalam pengurusan Pajak Bumi dan Bangunan Perdesaan dan Perkotaan dan sekaligus bertanya bagaimana kendala dalam proses pelaksanaan Implementasi Kebijakan Pajak Bumi dan Bangunan Perdesaan dan Perkotaan di Badan Pendapatan Daerah Kabupaten Bengkalis.

b. Kepala Bidang Penagihan dan Keberatan Bapak Syahruddin, SH, MH. Berperan sebagai pengawas terhadap penagihan atau pun persoalan keberatan dalam pengurusan Pajak Bumi dan Bangunan Perdesaan dan Perkotaan di Badan Pendapatan Daerah Kabupaten Bengkalis

c. Kasubbid Pengolahan Data dan Informasi Ibu Imelda Rosa, SH. Berperan sebagai menerima berkas permohonan serta langsung merekam atau memperbaiki berkas permohonan dan mencetak produk hukum.

d. Kasubbid Pembukuan PBB-P2 dan BPHTB Ibu Hj. Elidarwita, SE. Berperan sebagai pengarsipan administrasi produk hukum baik dari sedang di urus hingga sudah selesai di urus berbentuk yang telah legal.

e. Plt. Kepala UPT PBB-P2 Bapak Oki Farhadinata, SE. Berperan sebagai Implementor Kebijakan Pajak dalam hal meneliti konsep produk hukum yang telah diperbaiki lalu menyetujuinya berdasarkan SOP yang sudah ditentukan dan terakhir memaraf konsep produk hukum tersebut.

2. Wajib Pajak

Masyarakat Kabupaten Bengkalis yang merupakan sumber informan untuk melihat dan menilai 
bagaimana SOP Pelayanan PBB-P2 yang sudah di implementasikan sesuai dengan Peraturan Bupati Nomor 43 Tahun 2014, apakah sudah dirasakan atau berdampak secara langsung atau tidak ke masyarakat.

Data yang dikumpulkan kemudian dianalisa terdiri dari data primer dan data sekunder. Sesuai dengan tujuan penelitian yang telah dilakukan terkait dengan Implementasi Peraturan Bupati Nomor 43 Tahun 2014 tentang SOP Pelayanan PBB-P2 di Badan Pendapatan Daerah Kabupaten Bengkalis.

Pengumpulan data dalam penelitian ini dilakukan pada periode bulan juli sampai bulan november 2020. Penelitian ini dilakukan secara bertahap dari observasi, pengumpulan data, serta dokumentasi dan wawancara dengan beberapa informan yang telah dipilih oleh penelitian sebagai narasumber dalam penelitian ini. Analisis data dalam penelitian ini diawali dengan mengumpulkan data mentah yang telah di peroleh pada saat observasi, wawancara dan survei. Data mentah yang diperoleh baik dalam bentuk tertulis, soft copy dan rekaman ataupun catatan pada saat penelitian, kemudikan dikumpulkan untuk di satukan menjadi sebuah data dan informasi yang lebih sederhana untuk dibaca dan dipahami.

Kemudian hasil wawancara diidentifikasikan sesuai dengan pertanyaan yang diajukan oleh peneliti kepada beberapa narasumber yang sudah ditetapkan menjadi informan penelitian. Berikut merupakan analisis data yang digunakan oleh peneliti dalam melaksanakan penelitian tentang Implementasi Peraturan Bupati Nomor 43 Tahun 2014 tentang SOP Pelayanan PBB-P2 di Badan Pendapatan Daerah Kabupaten Bengkalis.

\section{HASIL DAN PEMBAHASAN}

Pada bab ini penulis menyajikan data-data dan informasi yang diperoleh dari penelitian di lapangan tentang bagai mana SOP pelayanan dalam pengurusan Pajak Bumi dan Bagunan Pedesaan dan Perkotaan di Kabupaten Bengkalis. Informasi tersebut di dapat berdasarkan wawancara dengan pihak yang terkait dalam penelitian, dari hasil terkumpul sejumlah data yang diperlukan tentang Implementasi Peraturan Bupati Nomor 43 Tahun 2014 Tentang SOP Pelayanan PBB-P2 di Badan Pendapatan Daerah Kabupaten Bengkalis.

\subsection{Implementasi Peraturan Bupati Nomor 43 Tahun 2014 Tentang SOP Pelayanan PBB-P2 Di Badan Pendapatan Daerah Kabupaten Bengkalis}

Suatu kebijakan publik yang telah disyahkan tidak akan bermanfaat apabila tidak diimplementasikan secara maksimal dan benar. Hal ini disebabkan karena implementasi kebijakan publik berusaha untuk mewujudkan kebijakan publik yang masih bersifat abstrak ke dalam realita nyata. Maka harus ada implementor yang konsisten dan profesional untuk mensosialisasikan isi kebijakan tersebut. Dengan kata lain, bahwa pelaksanaan kebijakan publik berusaha menimbulkan hasil (outcome) yang dapat dinikmati terutama oleh kelompok sasaran (target groups).

Gordon dalam Keban (2004:72) mengatakan implementasi berkenaan dengan berbagai kegiatan yang diarahkan pada realisasi program. Artinya implementasi terdapat di berbagai kegiatan yang tujuannya untuk menyelesaikan kegiatan atau program yang ditetapkan. Kemudian Jones dalam Widodo (2010:86) mengartikan implementasi sebagai Getting the job done -and" doing it. Pandangan tersebut merupakan pengertian yang sangat sederhana. Akan tetapi, dengan kesederhanaan rumusan seperti itu tidak berarti implementasi kebijaksanaan merupakan suatu proses kebijakan yang dapat dilakukan dengan mudah. Menurut Jones, pelaksanaannya menuntut adanya beberapa syarat, antara lain adanya orang atau pelaksana, uang, dan kemampuan organisasional, yang dalam hal ini sering disebut resources.

Dalam penelitian ini, penulis memfokuskan permasalahan yang dapat menerangkan bagaimana 
pelaksanaan SOP Pelayanan PBB-P2 di Kabupaten Bengkalis. Untuk mengetahui bagaimana Implementasi Peraturan Bupati Nomor 43 Tahun 2014 tentang SOP Pelayanan PBB-P2 penulis menggunakan konsep teori yang dikemukakan oleh Ripley Randal B. dan Grace A. Franklin dalam Meyzi, Adianto dan Hasim. Dimana dalam Implementasi Kebijakan Ripley Randal B. dan Grace A. Franklin berpandangan ada tiga variabel penting dalam mencapai keberhasilan implementasi kebijakan publik, yaitu :

1. Compliance/Kepatuhan

2. Kegiatan Rutinitas

3. Kinerja Kebijakan

Selanjtunya penulis akan menjelaskan masing-masing indikator tersebut menurut jawaban dari wawancara terhadap informan yang telah di lakukan sebelumnya dalam penelitian ini, untuk mengetahui tanggapan informan terhadap indikator-indikator tersebut. Dari pelaksanaan SOP Pelayanan PBB-P2 diatas terdapat beberapa kegiatan yaitu, sebagai berikut:

\subsubsection{Compliance/Kepatuhan}

Kepatuhan adalah fenomena yang mirip dengan penyesuaian diri. Perbedaannya terletak pada segi pengaruh legitimasi (kebalikan dengan paksaan atau tekanan sosial), dan selalu terdapat suatu individu, yakni pemegang otoritas. Kepatuhan didefinisikan sebagai sikap disiplin atau perilaku taat terhadap suatu perintah maupun aturan yang ditetapkan, dengan penuh kesadaran. Kepatuhan sebagai perilaku positif dinilai sebagai sebuah pilihan. Artinya individu memilih untuk melakukan, mematuhi, merespon secara kritis terhadap aturan, hukum, norma sosial, permintaan maupun keinginan dari seseorang yang memegang otoritas ataupun peran penting.

Kepatuhan dalam konsep implementasi kebijakan yaitu pengimplementasian kebijakan dalam bentuk dokumen perundang-undangan, peraturan pemerintah, program, yang dilaksanakan para implementor sesuai dengan apa yang tertuang didalam kebijakan tersebut tanpa melakukan tindakan yang berkebalikan dari kebijakan yang telah ditetapkan.

Kepatuhan dalam mengimplementasikan kebijakan, karena dengan adanya kepatuhan dalam menjalankan suatu kebijakan sehingga terhindarinya dampak dari pelanggaran yang dapat merugikan berbagai pihak baik itu dari birokrat maupun dari masyarakat. Kebijakan itu sendiri juga merupakan suatu pelindung bagi masyarakat agar tidak terjadinya penyalahgunaan kekuasaan yang dimiliki oleh pihak birokrat. Lebih lanjut lagi, seorang implementor diharuskan mematuhi kebijakan karna untuk menghindari persepsi negatif ataupun ketidakpatuhan yang akan dilakukan oleh masyarakat. Oleh karena itu, para implementor yang berperan dalam mengimplementasikan Peraturan Bupati Nomor 43 Tahun 2014 tentang SOP Pelayanan PBB-P2 di Badan Pendapatan Daerah Kabupaten Bengkalis harus mematuhi kebijakan tersebut.

Berkaitan dengan Implementasi Peraturan Bupati Nomor 43 Tahun 2014 tentang SOP Pelayanan PBB-P2 di Badan Pendapatan Daerah Kabupaten Bengkalis terdapat berbagai pihak yang terkait untuk merealisasikan kebijakan tersebut, salah satunya adalah diperlukannya pengawasan terhadap penagihan maupun pengajuan keberatan terhadap pengurusan pelayanan PBB-P2 ini. Hal itu berdampak terhadap kepatuhan yang harus dilakukan pihak pemerintah maupun masyarakat, karna segala yang berkaitan dengan pengurusan pelayanan PBB-P2 ini harus dijalankan secara efektif dan efisien.

Pengurusanan pelayanan PBB-P2 ini diperlukannya pengawasan yang dilakukan pihak dinas terkait, karna aka nada nantinya masyarakat yang tidak melakukan pengurusan pelayanan PBB-P2 ini. terdapat juga factor yang menyebabkan terjadinya masyarakat yang tidak melakukan pengurusan pelayanan PBB-P2 yaitu baik dari masyarakat yang tidak memperdulikan kebijakan yang ada maupun masyarakat yang merasa keberatan terhadap segala SOP yang telah diterapkan didalam pengurusan Pelayanan PBB-P2. Pengawasan yang dilakukan pihak wdinas bukan semata-mata karna ini mencari 
kesalahan yang dilakukan masyarakat tetapi juga bermanfaat untuk mengetahui bagaimana kondisi yang di alami masyarakat dalam mengikuti kebijakan yang ada ini. Oleh sebab itu pengawasan yang dilakukan agar menciptakan kondisi yang menggerakkan masyarakat untuk memiliki rasa kepatuhan dengan SOP pelayanan PBB-P2 ini. Dan juga memunculkan rasa kepatuhan dari pihak implementor dalam melaksanakan tugasnya.

Terjalankannya Implementasi Peraturan Bupati Nomor 43 Tahun 2014 tentang SOP Pelayanan PBB-P2 di Badan Pendapatan Daerah Kabupaten Bengkalis diperlukannya peran perancang agar sesuai dengan kebijakan tersebut. Perancangan diperlukan sebagai dasar agat terimplementasinya kebijakan tersebut secara efektif dan efisien, sehingga segala hal yang akan dilakukan dapat terproses secara sistematis dan meminimalisir segala dampak yang akan terjadi. segala hal yang sudah dirancang namun dapat tidak terlaksana sebagaimana mestinya. Hal yang menyebabkan tidak terlaksana dengan baik itu tidak luput dari pihak-pihak yang tidak bertanggungjawab dalam melaksanakan perannya.

Implementasi Peraturan Bupati Nomor 43 Tahun 2014 tentang SOP Pelayanan PBB-P2 di Badan Pendapatan Daerah Kabupaten Bengkalis masih terdapat ketidaksesuaian dengan harapan yang ada, karena pada indikator kepatuhan ini masih ditemukannya pihak yang tidak melakukan peran nya sebagai implementor sebagaimana mestinya, kemudian segala perancangan yang ada tidak dilakukan. Sehingga ketidakpatuhan itu dapat menyebabkan kerugian yang dialami masyarakat sendiri, karna kebijakan itu sendiri diperlukan sebagai perlindungan masyarakat agar diberikan pelayanan sesuai dengan SOP yang ada.

\subsubsection{Kegiatan Rutinitas}

Rutinitas merupakan suatu hal yang dilakukan secara terus-menerus sesuai prosedur yang teratur dan tidak berubah-ubah. Dan prosedur itu sendiri adalah tahapan-tahapan tertentu pada suatu program yang harus dijalankan untuk mencapai suatu tujuan. Jika kita gabungkan pengertian diatas bahwasanya rutin itu adalah suatu langkah-langkah atau tahapan-tahapan pada suatu program (aktivitas/kegiatan tertentu) pada suatu program yang telah dirancang untuk mencapai program, yang dilakukan secara teratur, tidak berubah-ubah. Selain itu rutin biasanya dilakukan secara terus-menerus dan berkelanjutan. Dengan demikian rutinitas sepertinya sudah memaku kita pada suatu aktivitas tertentu, tanpa kita memiliki pilihan.

Implementasi Peraturan Bupati Nomor 43 Tahun 2014 tentang SOP Pelayanan PBB-P2 di Badan Pendapatan Daerah Kabupaten Bengkalis merupakan kebijakan yang diperlukan untuk menjadi kegiatan rutinitas. Hal itu diperlukan karna setiap saat pasti adanya proses pembangunan yang dilakukan oleh masyarakat. Sehingga dengan adanya kegiatan rutinitas terkait PBB-P2 ini bisa menunjang administratif maupun PAD khususnya wilayah Bengkalis.

Terkait PBB-P2 ini apabila masyarakat yang kurang memahami terkait segala proses pengurusannya dapat menanyakan kepada sub bidang pembukuan dan informasi, karna segala prosedur yang ada memiliki berbagai tahap sehingga hal tersebut dapat menjadi penghambat masyarakat sendiri dalam pengurusan PBB-P2 ini. Namun pada saat ini masih adanya masyarakat yang memahami terkait proses pengurusan dan masih adanya sifat ketidakpedulian terhadap memahami proses pengurusan PBBP2 ini, sehingga mengakibatkan proses pembukuan yang tidak terlaksana dengan baik. Pembukuan yang harus dilakukan secara rutinitas tidak dapat dilaksanakan dan menimbulkan hambatan dalam segala pendataan yang ada.

Kunjungan lapangan yang dilakukan pihak dinas masih terdapat masyarakat yang tidak mengurus PBB-P2, karena mereka beranggapan bahwasan itu bukan merupakan kegiatan rutinitas yang dianggap begitu penting. Dan juga pengajuan keberatan yang dilakukanoleh masyarakat kepada pihak dinas terkait kurang memahami prosedur pengurusannya. Seharusnya pengurusan ini adalah kegiatan rutinitas yang 
berguna bagi masyarakat dalam jangka panjang maupun dilakukan secara terus menerus.

Implementasi Peraturan Bupati Nomor 43 Tahun 2014 tentang SOP Pelayanan PBB-P2 di Badan Pendapatan Daerah Kabupaten Bengkalis masih minimnya masyarakat yang kurang memahami dalam pengurusan PBB-P2 itu sendiri sehingga dapat menghambat dalam proses pembukuannya. Oleh karena itu, agar masyarakat dapat memahami terkait SOP PBB-P2 ini diperlukannya kegiatan rutinitas yang dilakukan pihak dinas untuk memberikan informasi dan pemahaman kepada masyarakat, sehingga kegiatan administratif dan pembukuan dapat dilaksanakan secara berkala menjadi rutinitas agar tersusun secara lebih baik.

\subsubsection{Kinerja Kebijakan}

Kebijakan publik merupakan serangkaian tindakan yang ditetapkan oleh pemerintah yang mempunyai tujuan tertentu berkenaan dengan masalah tertentu yang diorientasikan pada penyelesaian masalah publik. Kebijakan publik yang ditetapkan pemerintah diharapkan mampu mengatasi kebutuhan atau harapan terhadap suatu kondisi yang mempunyai dampak bagi banyak pihak. Tujuan dari kebijakan yang telah formulasikan dapat dicapai melalui pelaksanaan kebijakan tersebut atau diistilahkan dengan implementasi kebijakan.

Implementasi kebijakan Pajak Bumi dan Bangunan (PBB) di Badan Pendapatan Daerah Kabupaten Bengkalis jika dikaitkan dengan pendapat ahli yaitu Wayne Person dalam Widodo (2007:40) yang mengatakan bahwa agar dapat menimbulkan dampak yang dapat dinikmati oleh kelompok sasaran, policy statment (pernyataan kebijakan) perlu diimplementasikan, oleh karena itu tahap selanjutnya adalah implementasi kebijakan, pada tahap ini aktifitas analisis mencakupi interprestasi dan Sehingga pendapat yang dikemukakan oleh infroman tersebut sejalan dengan pendapat ahli, sehingga kebijakan tentang PBBP2 tersebut dapat terimplementasi pada masyarakat khususnya Badan Pendapatan Daerah.

Dapat juga dilihat bahwa hasil wawancara yang dikemukakan memberikan gambaran, di mana kepentingan kelompok sasaran pada kebijakan ini telah terpenuhi, yang ditunjukkan oleh keinginan masyarakat mengurus PBB-P2 disebabkan oleh kepentingan pribadi dari masyarakat yang membutuhkan PBB-P2 sebagai persyaratan untuk keperluan lainnya. Keperluan masyarakat yang mendesak ternyata dapat menimbulkan kemauan masyarakat untuk mengurus PBB-P2 di Kabupaten Bengkalis, hal ini dapat dikatakan bahwa masyarakat merasa bahwa kepentingan mereka terakomodir oleh adanya kebijakan tersebut, maka dapat digambarkan bahwa kebijakan tersebut dapat di pahami dan memberikan dorongan bagi masyarakat untuk mengurus PBB-P2, terutama bagi masyarakat yang hendak mengurus sesuatu dan dalam persyaratannya membutuhkan PBB-P2 seperti dalam pengurusan di Bank.

Kebijakan ini bertujuan untuk kepentingan masyarakat, dimana dengan keberadaan PBB-P2 dapat membantu pengurusan administratif yang dilakukan masyarakat di berbagai aktivitasnya karena dengan adanya PBB-P2 tersebut maka secara tidak langsung keabsahan bumi dan bangunan yang di miliki masyarakat terjamin bahkan dapat membantu pemerintah untuk meningkatkan potensi-potensi PAD yang terarah dan terencana.

Implementasi kebijakan tersebut bertujuan untuk meningkatkan PAD serta pembangunan di Kabupaten Bengkalis sehingga diharapkan sasaran kebijakan yang dalam hal ini masyarakat dapat menindaklanjuti keberadaan kebijakan tersebut. Kelompok sasaran kebijakan (target group) yaitu orang atau sekelompok orang, atau organisasi dalam masyarakat yang perilaku atau keadaannya ingin dipengaruhi oleh kebijakan yang bersangkutan, karena kebijakan PBB-P2 ini bertujuan untuk mengatasi suatu permasalahan publik yang umumnya di Indonesia dan khususnya di Kabupaten Bengkalis.

Sosialisasi atau penyampaian langsung dari pejabat yang menangani bidang tugas yang berhubungan dengan PBB-P2, para pegawai maupun masyarakat juga dapat melihat langsung atau mempedomani Peraturan Dareah tentang SOP PBB-P2 tersebut yang merupakan pedoman bagi seluruh aparatur Pemerintah Kabupaten Bengkalis dalam penerapan implementasi kebijakan PBB-P2, dimana di 
dalam Peraturan Daerah tersebut sudah jelas dan sudah terperinci tentang PBB-P2, sehingga kebijakan tentang PBB-P2 tersebut dapat terimplementasi dengan baik sesuai dengan aturan/pedoman yang ada.

\subsection{Faktor-faktor yang menghambat dalam melaksanakan Peraturan Bupati Nomor 43 Tahun 2014 Tentang SOP Pelayanan PBB-P2 Di Badan Pendapatan Daerah Kabupaten Bengkalis}

Faktor Penghambat dalam Implementasi Kebijakan Pajak Bumi dan Bangunan. Carl J Federick dalam Agustino (2008:7) mendefinisikan kebijakan sebagai serangkaian tindakan/kegiatan yang diusulkan seseorang, kelompok atau pemerintah dalam suatu lingkungan tertentu dimana terdapat hambatan-hambatan (kesulitan-kesulitan) dan kesempatankesempatan terhadap pelaksanaan usulan kebijaksanaan tersebut dalam rangka mencapai tujuan tertentu. Pendapat ini juga menunjukan bahwa ide kebijakan melibatkan perilaku yang memiliki maksud dan tujuan merupakan bagian yang penting dari definisi kebijakan, karena bagaimanapun kebijakan harus menunjukan apa yang sesungguhnya dikerjakan daripada apa yang diusulkan dalam beberapa kegiatan pada suatu masalah.

Implementasi Peraturan Bupati Nomor 43 Tahun 2014 tentang SOP Pelayanan PBB-P2 di Badan Pendapatan Daerah Kabupaten Bengkalis dalam menjalankan kebijakan peraturan tersebut pastilah terdapat factor-faktor penghambat dalam mengimplementasikannya. pengawasan oleh Badan Pendapatan Daerah terhadap para kolektor yang ada di desa mengingat karena jaraknya antara pusat pelayanan dengan wajib pajak dan subjek pajak agak berjauhan. Hal tersebut menjadi salah satu factor penghambat yang signifikan dalam terjalankannya pengawasan PBB-P2 yang lebih baik

.Berdasarkan hasil penelitian pada Badan Pendapata Daerah Kabupaten Bengkalis yang telah diuraikan diatas, maka beberapa hambatan atau permasalahan yang dijumpai dalam rangka implementasi kebijakan PBB-P2 pada Badan Pendapatan Daerah antara lain masalah tentang jangkauan geografis, terutama wilayah-wilayah pedesaan yang ada diperbatasan, jangkauan pengawasan oleh Badan Pendapatan Daerah terhadap para kolektor yang ada di desa mengingat karena jaraknya antara pusat pelayanan dengan wajib pajak dan subjek pajak agak berjauhan. Kemudian dalam mengimplementasikan peraturan terkait PBB-P2 ini berdampak dari sisi anggaran, dan juga fasilitas yang dibutuhkan pihak dinas.

Disamping itu mutasi pejabat juga menjadi permasalahan / kendala dalam mengimplementasikan kebijakan PBB-P2 tersebut, dan hambatan yang paling berpengaruh dalam mengimplementasikan kebijakan Pajak Bumi dan Bangunan tersebut adalah masalah sarana dan prasarana kerja atau ruangan yang ada pada Badan Pendapatan Daerah sangatlah tidak memadai sehingga hal tersebut menjadi hambatan dalam rangka implementasi kebijakan PBB-P2 pada Badan Pendapatan Daerah. Kebijakan PBB-P2 pada Badan Pendapatan Daerah diperlukannya sumber daya yang memadai dengan menyatunya pegawai/staf sesuai dengan Bidangnya masing-masing, namun di karenakan terbatasnya ruangan yang ada pada Badan Pendapatan Daerah memicu kurang maksimalnya kinerja yang dilakukan pegawai.

Kendala dalam Implementasi Peraturan Bupati Nomor 43 Tahun 2014 Tentang SOP Pelayanan PBB-P2 di Badan Pendapatan Daerah Kabupaten Bengkalis yaitu Faktor geografis wilayah Kabupaten Bengkalis yang terdiri dari beberapa pulau. Kecamatan Siak Kecil, Bukit Batu, Bandar Laksamana, Talang Muandau, Pinggir, Mandau dan Bathin Solapan berada di Pulau Sumatera, Kecamatan Rupat dan Rupat Utara berada di Pulau Rupat, Kecamatan Bantan dan Bengkalis berada di Pulau Bengkalis. Begitu juga letak wilayah pedesaan-pedesaan yang sangat jauh dari UPT Pendapatan Kecamatan sehingga menimbulkan kurangnya PAD yang masuk akibat belum terlalu efektif nya proses pengawasan yang dilakukan pihak dinas kelapangan karna factor yang ada. Dan juga akibat keterbatasan wilayah karena kondisi geografis mengakibatkan kurangnya akses pelayanan masyarakat dalam mengurus PBB-P2 di Kabupaten Bengkalis. 


\subsection{Upaya Badan Pendapatan Daerah Bengkalis dalam Implementasi Peraturan Bupati Nomor 43 Tahun 2014 Tentang SOP Pelayanan PBB-P2 di Badan Pendapatan Daerah Kabupaten Bengkalis}

Menhadapi segala hambatan ataupun kendala yang di alami diperlukan suatu upaya agar hambatan tersebut dapat terselesaikan. Upaya itulah yang menjadi pendukung agar suatu kebijakan ataupun program yang ada bisa terealisasi sebaik mungkin. Adapun Upaya yang dilakukan dalam mengatasi hambatan Implementasi Peraturan Bupati Nomor 43 Tahun 2014 Tentang SOP Pelayanan PBB-P2 Di Badan Pendapatan Daerah Kabupaten Bengkalis adalah dengan Berbagai inovasi telah dilakukan oleh Badan Pendapatan Daerah Kabupaten Bengkalis untuk mempermudah penerapan SOP Pelayanan PBB-P2 ke masyarakat. Badan Pendapatan Daerah telah melakukan upaya agar masyarakat yang kondisinya jauh maupun terkendala baik dari waktu, sarana dan prasarana, Pemerintah mengadakan sistem Aplikasi SISMIOP yang berbasis web, aplikasi ini bisa diimplementasikan di UPT Pendapatan Daerah setiap Kecamatan. Wajib Pajak yang berada di luar Pulau Bengkalis tidak perlu datang ke UPT PBB-P2 yang berada dipulau Bengkalis, cukup mendatangi UPT Pendapatan Daerah terdekat. Dengan adanya system aplikasi yang dapat mengurus PBB-P2 dalam bentuk aplikasi ini dapat menghemat masyarakat dari segi waktu hingga estimasi budget yang dubutuhkan masyarakat.

Dalam mengupayakan alternatif agar akses pengurusan PBB-P2 ini dapat terimplementasikan dengan baik, juga diperlukannya kerja sama dengan berbagai pihak terkait yang dapat meminimalisir kendala yang ada. Pemerintah daerah Kabupaten bengkalis telah melakukan kerja sama terhadap berbagai pihak terkait agar meminimalisir hambatan ataupun kendala dalam mengimplementasikan kebijakan dalam proses pengurusan PBB-P2. Pihak-pihak terkait yang menjalin kerja sama dalam Implementasi Peraturan Bupati Nomor 43 Tahun 2014 Tentang SOP Pelayanan PBB-P2 Di Badan Pendapatan Daerah Kabupaten Bengkalis yaitu sebagai berikut:

1. Badan Pertanahan Nasional

Badan Pendapatan Daerah dan Badan Pertanahan Nasional Kabupaten Bengkalis telah melaksanakan Host to host terkait Inquery data PBB-P2 (Bapenda) dan pengiriman data transaksi peralihan (BPN)

2. KPP Pratama Bengkalis

Dalam Peraturan Bersama Menteri Keuangan Republik Indonesia dan Menteri Dalam Negeri Republik Indonesia Nomor 213/PMK.07/2010, Nomor 58 Tahun 2010 Tentang Tahapan Persiapan Pengalihan Pajak Bumi Dan Bangunan Perdesaan dan Perkotaan sebagai Pajak Daerah, Direktorat Jenderal Pajak bertugas dan bertanggung jawab mengkompilasi standard operating and procedure (SOP) terkait PBB-P2 sebagai bahan acuan Pemerintah Daerah dalam menyusun SOP

3. Kepala Desa/Lurah

Dalam hal permohonan Wajib Pajak yang diajukan secara kolektif, dibutuhkan surat keterangan yang mendukung alasan dari Kepala Desa/Lurah/Instansi terkait

4. Petugas PBB-P2 di setiap Kelurahan/Desa

Salah satu fungsi petugas PBB-P2 disetiap Desa dan Kelurahan adalah membuat laporan pemutakhiran data/perbaikan data Surat Pemberitahuan Pajak Terutang (SPPT) atas data yang tidak valid atau tidak benar.

5. Tempat Pembayaran

Bank Riau Kepri, Bank Negara Indonesia 46, Bukalapak, Tokopedia, Traveloka, LinkAja, Gopay dan Indomaret

Berdasarkan pemaparan diatas telah disebutkan berbagai pihak terkait yang menjalin kerja sama dengan pihak Badan Pendapatan Daerah, dan juga telah dijelaskan bagaimana peran yang dilakukan pihak-pihak terkait tersebut. Sehingga upaya Badan Pendapatan Daerah dalam mengurangi hambatan ataupun kendala yang di alami masyarakat dapat terminimalisir. 


\section{KESIMPULAN}

Hasil penelitian dan analisa yang sudah penulis lakukan memberikan beberapa kesimpulan dan saran antara lain:

1. Implementasi Peraturan Bupati Nomor 43 Tahun 2014 tentang SOP Pelayanan PBB-P2 di Badan Pendapatan Daerah Kabupaten Bengkalis diperlukannya peran perancang agar sesuai dengan kebijakan tersebut. Perancangan diperlukan sebagai dasar agat terimplementasinya kebijakan tersebut secara efektif dan efisien, sehingga segala hal yang akan dilakukan dapat terproses secara sistematis dan meminimalisir segala dampak yang akan terjadi. Implementasi kebijakan tersebut bertujuan untuk meningkatkan PAD serta pembangunan di Kabupaten Bengkalis sehingga diharapkan sasaran kebijakan yang dalam hal ini masyarakat dapat menindaklanjuti keberadaan kebijakan tersebut.

2. Ada beberapa faktor yan menjadi penghambat dalam pelaksanaannya Implementasi Peraturan Bupati Nomor 43 Tahun 2014 Tentang Sop Pelayanan PBB-P2 Di Badan Pendapatan Daerah Kabupaten Bengkalis adalah pertama Faktor geografis, wilayah Kabupaten Bengkalis terdiri dari beberapa pulau. Kecamatan Siak Kecil, Bukit Batu, Bandar Laksamana, Talang Muandau, Pinggir, Mandau dan Bathin Solapan berada di Pulau Sumatera, Kecamatan Rupat dan Rupat Utara berada di Pulau Rupat, Kecamatan Bantan dan Bengkalis berada di Pulau Bengkalis. Begitu juga letak wilayah pedesaanpedesaan yang sangat jauh dari UPT Pendapatan Kecamatan. Kondisi ini sedikit menghambat akses pelayanan ke masyarakat. Kedua adalah faktor Sumber daya Manusia (SDM) yang belum memadai. Ketiga, keuangan yang terbatas.

3. Adapun upaya yang dilakukan oleh Badan Pendapatan Daerah (BAPENDA) Kabupaten Bengkalis dalam Implementasi Peraturan Bupati Nomor 43 Tahun 2014 Tentang Sop Pelayanan PBB-P2 Di Badan Pendapatan Daerah Kabupaten Bengkalis yakni, melakukan banyak inovasi yakni Aplikasi SISMIOP yang berbasis web, melakukan kerjasama dengan berbagai instansi baik Swasta maupun negeri.

\section{SARAN}

Berdasarkkan hasil penelitian dan pembahasan yang sudah di uraikan, berikut penulis uraikan beberapa saran yang di harapkan dapat menjadikan masukan dan pertimbangan untuk Badan Pendapatan Daerah Kabupaten Bengkalis dan terkhususnya kepada masyarakat maupun pembaca lainnya. Berikut saran yang penulis berikan yaitu :

1. Berdasarkan kesimpulan yang didapatkan, disarankan kepada kepala Badan Pendapatan Daerah Kabupaten Bengkalis Utara agar meningkatkan kualitas pegawai melalui pendidikan dan pelatihan serta menambah pegawai dan menempatkannya sesuai dengan pendidikan yang dimilikinya. serta penambahan/peningkatan pengalokasian anggaran dan pemberian insentif secara rutin kepada pegawai yang ada, Selain itu perlu memperbaiki cara pelayanan agar tidak berbelit dan lebih cepat guna memenuhi keinginan masyarakat yang mengurus PBB P2 agar menjadi patuh.

2. Standar Operasional Prosedur di lingkungan Organisasi Perangkat Daerah, Badan Pendapatan Daerah Kabupaten Bengkalis Provinsi Riau merupakan salah satu langkah dalam mendukung pelaksanaan reformasi birokrasi. Dengan Standar Operasional Prosedur (SOP), setiap pegawai dan pejabat dapat melaksanakan pekerjaannya dengan efisien, memberikan kemudahan dalam memantau hasil pekerjaan, bekerja makin terarah dan bermanfaat bagi perbaikan kinerja organisasi.

3. SOP ini harus selalu dievaluasi dan senantiasa bergerak dinamis sesuai dengan tuntutan visi dan misi Badan Pendapatan Daerah Kabupaten Bengkalis Provinsi Riau sebagai akibat adanya tuntutan reformasi birokrasi dan kemajuan ilmu dan teknologi informasi. Standar Operasional Prosedur ini, 
diharapkan setiap unit kerja di lingkungan Badan Pendapatan Daerah Kabupaten Bengkalis Provinsi Riau dapat menjalankan tugas pokok dan fungsinya terutama dalam meningkatkan penerimaan pendapatan asli daerah (PAD), khususnya pajak daerah serta pada akhirnya dapat meningkatkan pelayanan prima kepada masyarakat.

\section{DAFTAR PUSTAKA}

[1] Agustino, L. (2008). Dasar-dasar kebijakan publik. Bandung: Alfabeta

[2] Arikunto, S (2002). Prosedur penelitian suatu pendekatan praktek. Jakarta: PT. Rineka Cipta

[3] Bagijo, Himawan Estu. (2011). Pajak dan Retribusi Daerah sebagai Sumber Pendapatan Daerah (Studi Kasus di Kabupaten/Kota dan Pemerintah Provinsi di Jawa Timur). Jurnal Perspektif, Vol. XVI No. 1, Edisi Januari.

[4] Bewa Ragawino. 2003. Desentralisasi dalam Kerangka Otonomi Daerah di Indonesia. Makalah. Fisip Universitas Padjadjaran. Bandung.

[5] Darmono. (2007). Perpustakaan Sekolah: pendekatan aspek manajemen dan tata kerja. Jakarta: Grasindo.

[6] Ekotama, Suryono (2010). Cara Gampang Bikin Standard Operating Procedure. Yogyakarta: Media Pressindo.

[7] Ida, Nuraida. (2008). Manajemen Administrasi Perkantoran. Yogyakarta: Kanisius.

[8] Laksmi, dkk. (2008). Manajemen Perkantoran Modern. Jakarta: Penerbit Pernaka

[9] Mardiasmo. (2003). Perpajakan.Yogyakarta: ANDI Yogyakarta.

[10] Moekijat. (2008). Adminitrasi Perkantoran. Bandung: Mandar Maju.

[11] Nugroho, R. (2003). Kebijakan Publik, Formulasi, Implementasi dan Evaluasi. Jakarta: PT. Elex Media Computindo.

[12] Sailendra, Annie. (2015). Langkah-Langkah Praktis Membuat SOP. Cetakan Pertama, Yogyakarta : Trans Idea Publishing.

[13] Siahaan, Marihot P. (2010). Pajak dan Retribusi Daerah. Jakarta: PT. Raja Grafindo Persada.

[14] Simanjuntak, Timbul Hamonangan dan Imam Mukhlis. (2012). Dimensi Ekonomi Perpajakan Dalam Pembangunan Ekonomi. Jakarta: Raih Asa Sukses.

[15] Stup, R. (2001). Standard Operating Procedures : A Writing Guide. Dairy Alliance, Penn State University .http://dairyalliance.psu.edu/pdf/ud011. pdf. 
[16] Suandy, Erly. (2011). Perencanaan Pajak. Jakarta: Salemba Empat.

[17] Subarsono A.G. (2005). Analisis Kebijakan Publik: Konsep Teori dan Aplikasi. Pustaka Pelajar, Yogyakarta, Indonesia.

[18] Tambunan, Rudi. (2008). Standard Operating Prosedures (SOP). Jakarta: Maiestas Publishing.

[19] Subarsono A.G. (2005). Analisis Kebijakan Publik: Konsep Teori dan Aplikasi. Pustaka Pelajar, Yogyakarta, Indonesia.

[20] Sulistiyani, A.T dan Rosidah. (2003). Manajemen Sumber Daya Manusia. Yogyakarta: Graha Ilmu.

[21] Rahmawati, I. Z. (2018). Perbandingan Pembangunan Berkelanjutan Negara Berkembang Dan Negara Maju (Studi terhadap Pembangunan Berkelanjutan di Indonesia dan China), (May).

[22] Rustiadi, E. (2016). Permasalahan Pembangunan Wilayah Riau Menyongsong Otonomi Wilayah, (February), 1-28.

[23] Santoso, E. B. (2019). Partisipasi Masyarakat dalam Pembangunan di Kota Balikpapan, (February). https://doi.org/10.33701/jiwbp.v8i2.292

[24] Wahab, S.A. (2008). Analisis Kebijaksanaan, dari Formulasi keImplementasi Kebijaksanaan Negara. Jakarta : Bumi Aksara. 